\title{
Redrawing Dystopian Borders: A Decolonial Reading of Vernacular Dystopias through Mahasweta Debi's Short Stories
}

\section{Sukla Chatterjee \\ ORCID iD: https://orcid.org/0000-0002-2039-6976}

\begin{abstract}
This article analyses three exemplary short stories of the Indian literary stalwart and activist Mahasweta Debi (1926 - 2016), to trace how literary dystopias can set aside their gentrified first world status and their usual connection with futuristic societies, to evolve with and accommodate the demands and realities of decolonial and postcolonial societies. Dystopias, especially literary dystopias, since their inception, have been one of the primary cultural forms that reflects in a creative way, the fear, disillusionment, and collapse of a world order and social structure while serving as a warning of an improbable probability. This article demonstrates that even though twentieth-century Bengali literature lacks genre specific nomenclature and analogous category of literary dystopias, however that in no way signifies a lack in such writings in the many vernacular languages, which is showcased through the reading of Debi's Bengali short stories. It further exemplifies that even in a limited span of a short story, it is possible to capture the acute and poignant realities of decolonial societies: realities that blur the distinction between the present and the dystopian futurism.
\end{abstract}

Keywords: literary realism, decolonial societies, literary dystopias, Mahasweta Debi, Bengali literature, postcolonial literature, dystopian short stories, hunger, starvation, violence 


\section{Sukla Chatterjee}

\section{Introduction ${ }^{1}$}

The primary aim of this article is to trace the evolution and accommodation of dystopian elements in vernacular Indian literatures, taking the short stories of the Indian writer Mahasweta Debi (1926 - 2016) as examples. This article aims to bring the canon of dystopia out of its gentrified first world status and its usual association with futuristic hypothetical societies, to connect it with realistic yet largely unacknowledged dystopian elements that are present in postcolonial and vernacular Indian literatures. Postcolonial dystopias are one of the many cultural forms where disillusionment, disappointment, and breakdown of the social structure of a postcolonial nation is productively illustrated. This article, in its limited scope, is based on three exemplary short stories of the Bengali literary stalwart and activist, Mahasweta Debi. Twentieth-century Bengali literature does not have an analogous and comprehensive category of utopian and dystopian writings, nor is there a distinct terminology, which qualifies as an equivalent of dystopia.

However, that does not signify an absence of fantastic, satiric, anticolonial, anti-totalitarian, or anti-industrialisation depiction of the society therein. Social satire, as a form of dystopian writing in Bangla ${ }^{2}$ literature made its mark already in the $19^{\text {th }}$ century, but since most of these writings were in the garb of social satire or political treaties, there is an absence of a genrespecific nomenclature (see Sen 2012: 123 - 146). Despite some active and valuable contribution from mainly South Asian scholars (see Bagchi 2012), the lapse in establishing dystopia as a genre in postcolonial Bangla literature is symbolic of the tendency to overlook vernacular contributions to the canon of dystopian literature, and this is further complicated by selective acknowledgement and inclusion of Indian writers writing in English, thereby overlooking the diverse and assorted tributaries of vernacular dystopian writings. Mahasweta Debi is a globally acknowledged writer whose works consolidate the challenge that postcolonial writers like her pose at the

\footnotetext{
${ }^{1}$ The author is extremely grateful to Prof. Rozena Maart and to the anonymous copy editor and reviewer(s) for their effort and support, and for the meticulous and valuable feedback on the article.

${ }^{2}$ The more common anglicised version is Bengali. In this article, it refers to the literature and culture from West Bengal, a state in eastern India with Calcutta (Kolkata) as the capital city. It was the capital of British India from 1772-1911.
} 
association of literary dystopias with futuristic writings. The article will develop and clarify the areas of overlapping and distinction between social realism and dystopian writing, and for this I focused on Debi's contribution towards experimenting with and establishing dystopian narratives in the limited expanse of a short story. The calibre and finesse of these laconic compositions exemplify that the despair and urgency of the dystopian realities of the 'third world' can be as analogously and deftly demonstrated in the confined span of a short story as that of the more established and expansive form of novel. At the onset, it is important to trace how literary genres, and in this case, the genre of dystopia, travel and connect across cultures, societies, and nations.

One of the most important aspects that emerged from the works of scholars on genre theory is the cultural specificity of genres, since genre illuminates not only the social structure, but also the culture, and in extension the nation through its connection with specific historical periods, social interaction, and use of distinct rhetoric and language (Mayes 2003; Ilot 2015). Studying genres across cultures can give us a glimpse of how different cultures access, relate to, and modify different genres. The redrawing of the dystopian borders that I have included in the title of this article alludes to the shifting boundaries of a genre and its abilities to expand, evolve, and adapt to unique situations of postcolonial societies that require such accommodation. Vernacular dystopias have been the outcome of a new set of fears, anxieties, and a revised version of the apocalypse. This renegotiation and revisiting of the generic boundaries of dystopia can also be a part of the regentrification (and alternatively regentrification) process (Ilot 2015: 5f), a term Ilot uses in the context of traditionally marginalised authors. While Mahasweta Debi does not fall in the category of marginalised writers, I think her works can be reexplored as chronicles of 'third world' dystopian narratives, adequately redefining the aesthetics, style, and nuances of the genre as well as stretching and experimenting with the conventions. Genre theorists often argue that genre and nation work in similar fashion, both with porous boundaries and trying to contain the whole in its mobility and multiplicity. Harnessing the instabilities of genre boundaries, one can delve into the politics of inclusion and exclusion and thereby redrawing the borders of both the genre and the nation (Ilot 2015: 6). Furthermore, literary forms and genres are linked historically to political and social conditions of a nation and they respond to political situations of a society. To give an example, realism in Bangla literature developed (which was 


\section{Sukla Chatterjee}

a distinct departure from Rabindranath Tagore's brand of humanism and romanticism) during the turbulent conditions of the mid-20th century when India was grappling with several crises in the form of the infamous famine of 1943 and the imminent partition of India and Pakistan in 1947. Furthermore, Rick Levine conjectures that literary forms themselves, exert political power. While forms respond to the forces operating in a society and contains diversity at its heart, it also constrains because 'it imposes powerful controls and containments' (Levine 2015: 4). It is this constraining factor which works as a checklist for the arrangement of elements, structures, and patterns, that lends form to its uniqueness and rigour. However, this rigour and structure is actually a reflection of the binary patterns of the structure of the human communities themselves (Levine 2015: 5), argues Levine ${ }^{3}$. We find such binarism in the development of utopian and dystopian forms in societies where binaries of rich/ poor, developed/ underdeveloped, free/ captive, colonialism/ imperialism have made their way into utopian and dystopian visions of societies. In fact, in this case, social structures and situations have determined the parameters of the forms.

There is one last aspect of forms that Levine calls affordances, which further solidifies our concept of its structure as in what it can include and exclude. Simply put, affordances are what forms can afford to do or represent. Forms, while moving across time and space, carry with them the specific arrangements and patterns of what they are capable of doing. This capability is embedded in the inclusion and exclusion: '[...] a specific form can be put to use in unexpected ways that expand our general sense of that form's affordances. Rather than asking what artists intend or even forms do, we can ask what potentialities lie latent - though not always obvious - in aesthetic and social arrangements (Levine 2015: 6). This article precisely explores the potentialities of the form of dystopia when it represents a postcolonial society:

${ }^{3}[\ldots]$ forms travel $[\ldots]$ by moving back and forth across aesthetic and social materials. [...] human communities were organised by certain universal structures. The most important of these were binary oppositions- masculine and feminine, light and dark which imposed a recognisable order across social and aesthetic experiences, from domestic spaces to tragic dramas. Structuralism came under fire for assuming that these patterns were natural and therefore inexorable, but one does not have to be a structuralist to agree that binary oppositions are a pervasive and portable form, capable of imposing their arrangements on both social life and literary texts (Levine 2015: 5). 
how dystopian thinking and social realism combine to further consolidate the aesthetics of dystopianism through the portrayal of systemic repression and annihilation of marginalised people. Debi exemplifies that in the context of postcolonial societies, one need not to venture to an imagined future to visualise the end; it is near and at hand. Besides questioning the canonical dystopian worldview, Debi as a postcolonial writer, also articulates and questions the essence and parameters of the canon by offering alterity, since her stories rewrite the conventions of the genre from within and she navigates and articulates these conventions by identifying how the fear, hopelessness, and sense of doom, that lies at the heart of dystopia can be negotiated through her narratives.

The western definition of dystopia (see Chatterjee 2019) evokes an apocalyptic vision of chaos, wreckage, and annihilation, usually adhering to the political, environ-mental, and technological aspects of society. Dystopia, consisting of the Greek words dus and topos, signifies a bad place, a failed utopia. The usage was coined around 1747 but gained popularity in the late 20th century in the Western world (see Boller \& Voigts-Virchow 2015), mainly within apocalyptic science fiction (see Claeys 2017). With their focus on the society, literary dystopias usually bring forth a social-political message,

[t]he overall strategies of the dystopian novel are those of political satire. The writer offers militant criticism of specific aberrations in our own, present social-political system by pointing out their potentially monstrous consequences in the future (Gottlieb 2001: 13).

There are distinctions within the genre, for example, Moylan distinguishes between 'classic dystopia' and 'critical dystopia', both of which are socially critical, allowing 'readers and protagonists to hope by resisting closure: the ambiguous, open endings of these novels maintain the utopian impulse within the work'4, and the 'anti-utopia', 'pseudo-dystopia', and 'anti-critical dystopia', which do not offer a horizon of hope but focuses more on the cruelty, deception, and inherent venality of human nature. Fredric Jameson talks about two different types of dystopian text: 'the 'critical dystopia', which functions by way of a warning, through the 'if this goes on principle'; and the 'anti-

${ }^{4}$ For a detailed discussion see Baccolini, Moylan (eds.) 2003. As quoted in Milner (2009: 833). 


\section{Sukla Chatterjee}

Utopia' proper, which springs from the quite different conviction that human nature is so inherently corrupt, it can never be salvaged by 'heightened consciousness of the impending dangers' (Milner 2009: 831).

This article focuses on three short stories, 'Sishu' (Children), 'Sandes' (Sweet), and 'Mahdu: A Fairy Tale' (translated by the author), written by Mahasweta Debi, one of the greatest Bengali authors of the 20th century, with an attempt to read dystopian writings in the light of realism of postcolonial societies. Debi's portrayal of the evils of a repressive state apparatus, a regressive social structure and its onslaught on marginalised human lives veers more towards the portrayal of anti-Utopia than any other abovementioned forms of the canon. Her stories portray a certain disillusionment and hopelessness that forms a part of the everyday functioning of postcolonial societies, which are turned into spaces on which the unbelievably corrupt or the unthinkably bad plays their role to blur the boundaries between what could happen and what is happening now.

It can be safely assumed that Mahasweta Debi, in these narratives, did not undertake to rework nor appropriate the canonical western dystopian model and hence did not contribute to reinforcing the centrality of the genre. What she did was to narrate the life conditions of the indigenous population almost with journalistic faithfulness. It is my conscious choice to read her texts as dystopian additions from the ex-colonies, to broaden the horizon of the Western canon of dystopian literature and redefine it to include similarly themed literature from the subcontinent. In the process, if I have subjected the narratives to some of the parameters of Western dystopian writings, that is simply for the sake of understanding and reference, since these exemplary stories are unique contributions capable of standing on their own. Vernacular dystopian literature does not require validation from Western/Eurocentric models of writing, and I have used the term dystopia for lack of another suitable vernacular term. In a previously published article, I have used keyamat sahitya [apocalyptic literature] to refer to vernacular dystopias, but Debi's stories are not exactly apocalyptic in nature. What I wish to achieve through this article, is to show that vernacular literature has a distinct dystopian branch of writings and once brought to focus, they can significantly enrich and broaden the horizon of literary dystopias. Mahasweta Debi (1926 - 2016), one of the most celebrated and widely translated Bengali writers and a notable activist is known for her writings on the ostracised Indian indigenous tribal population and minorities. Debi's writings explore the failures of decolonisation and the 
ensuing crisis of a postcolonial state mainly through the indigenous populartion's survival conditions. Gayatri Spivak (1996), in her assessment of Debi's creative political writings and her positioning of the subaltern in the consciousness of a decolonised nation notes that although decolonisation operates on a logic of reversal from colonisation, whereby,

[t]he new nation is run by a regulative logic derived from a reversal of the old colony from within the episteme of the postcolonial subject, the exclusion of the subaltern is not reversed into an inclusion in a decolonised society, but, there is however a space that did not share in the energy of the reversal, a space that has no firmly established agency of traffic with the culture of imperialism. [...] Conventionally, this space is described as the habitat of the subproletariat or the subaltern. Mahasweta's fiction suggests that this is the space of the displacement of the colonisation-decolonisation reversal. This is the space that can become, for her, a dystopic representation of decolonisation as such ${ }^{5}$ (Landry, MacLean 1996: 164).

This dark cave-like space, frozen in time, and imbibing the suffocating regimes of imperial domination long after imperial domination is said to have faded away, or where imperial domination reinvents itself to suit the postcolonial structure, is what we find in the pages of Debi's narratives. Her dystopian space is not another society one can have nightmares about, but a chunk of this same society coexisting in the same temporal and spatial dimensions.

The inhabitants of this dystopic space bear the prefix of 'sub', signifying under, below, beneath, imperfect, not quite and displacement is the core of this space, not just on the level of the colonisation-decolonisation reversal but also for the displacement of the sub-bodies. Through the short stories, I situate this embodied displacement of the people and at times the process of disembodying them as well as the space where the dystopic tragedy of decolonisation unfurls. Furthermore, in a society where the majority of the population is forced to forge a till-death-do-us-part relationship with poverty and hunger, it is not surprising that crises-ridden reality would constitute the core of Debi's anti-Utopia. Furthermore, the calibre and finesse of these laconic compositions exemplify that the despair and urgency of the dystopian

\footnotetext{
${ }^{5}$ All italics are from the original text.
} 


\section{Sukla Chatterjee}

realities of the 'third world' can be as analogously and deftly demonstrated even in the confined span of a short story as that of the more established form of novels. Even though fantasy and fiction have ruled the genre, realism is still a major component of literary dystopias. In the realm of Western dystopian literature, realistic dystopias have garnered more attention and popularity. Nineteen Eighty-Four (1949) 'inspired dread above all, that is precisely because its materials are taken from the real world' (Meyers 1975: 268). So is The Year of the Flood (2009), which the author Margaret Atwood herself claims as 'fiction, but the general tendencies and many of the details in it are alarmingly close to fact' (Atwood 2009: 443).

Relatability makes the horror of dystopia more real. As Claeys sums up,

[T] he writer's function is to tell the truth, not to sell dreams. And even if we assign utopia the latter task, dystopia's is surely the former (2017: 431).

In the vernacular context, literature's engagement with reality is well articulated in Premchand's Presidential address delivered at the First All India Progressive Writers' Conference on 10 April 1936. He remarked:

Literature properly so-called is not only realistic, true to life, but is also an expression of our experiences and of the life that surrounds us. It employs easy and refined language which alike affects our intellect and our sentiments. Literature assumes these qualities only when it deals with the realities and experiences of life .... Literature can be best defined as a criticism of life (Premchand 2011: 82).

In the 20th century Bengali literary scenario, bastabbadi sahitya (realistic literature) also made its mark by virtue of prominent literary figures' insistence on realism as a literary technique. Their endeavour gave rise to a form of resistance, which came from within the established literary structure that heralded modernism in Bangla literature. It is important to trace the advent of realism in Bengali literature since dystopia and realism are very closely linked in the context of vernacular dystopian narratives. Depiction of famine, especially after the deadly famines of 1770 and 1943, became a key subject of literary production. Outstanding Bangla novelists like Tarashankar Bando- 
padhyay $^{6}$ and Bankim Chandra Chatterjee ${ }^{7}$ used famine in their seminal works. Especially Chatterjee in Anandamath (Abbey of Bliss 1882), which is counted as one of the most important contribution to the history of Bangla literature, describes famine-ridden Bengal of 18th century as the dystopia of Muslim rule. Similarly, Rabindranath Tagore's Tasher Desh (Land of Cards) a musical written in 1933 highlights a dystopia of fascism, regimentation, machine efficiency, and lack of creativity and freedom, which seems to coincide in timing with Hitler's rise to power in Europe. The brand of literary realism that was championed by the $\mathrm{Kallol}^{8}$ group of writers is further consolidated by Mahasweta Debi. Debi's portrayal of the conditions of the marginalised, subaltern lives creates her signature realism that iconises her protagonists. In an Orwellian fashion, she narrates the truth often depriving her readers of hope, because the lives she narrates are often without hope and the despondency that is disseminated to her readers is only a fraction of what her subjects go through on a daily basis.

While Debi's exemplary short stories discussed here posit subaltern individuals and groups against societies to bring out the clash between the two, which is a prominent dystopian trope, her characters are often the representatives of the classes to which they belong. Her account of the systemic abuse of tribal populations, the poor, and women weaves a dystopian society, which is very familiar and present. Debi's works are a powerful mixture of facts and creativity, where literary devices and her unique narrative techniques like chaotic registers, lend power, poignancy, and consolidation to her plots, which are often based on her own first-hand experiences of working with her subjects. Organised injustice lies at the heart of dystopia and dystopian narratives operate on the distorted principle of 'the deliberate miscarriage of justice' (Gottlieb 2001: 10). In Debi's Sishu, we see this deliberate miscarriage of justice at the hands of a repressive government. The story was first published

${ }^{6}$ Bangla novelist lived from 1898-1971. See Chatterjee (2019) available at https://olh.openlibhums.org/papers/10.16995/olh.358/\#

${ }^{7}$ Bankim Chandra Chatterjee (1838 - 1894) is considered a key figure of the Bangla literary renaissance; he was a novelist, poet and journalist, famed for composing Vande Matarm (Hail the Mother) which became a clarion call for India's freedom movement.

8 See discussion on realism in Bengali literature: Chatterjee (2019) and Bhattacharya (2017: 57 - 88). 


\section{Sukla Chatterjee}

in 1979 and underlines a government's conspiracy against its own people ${ }^{9}$. It has received critical acclaims and scholarly attention mostly for its importance from an ecocritical perspective.

The plot is set on a distinct topos, Lohri, which is situated at the border of Ranchi, Sarguja, and Palamou (the provincial districts). The landmass is described as dry and burnt, emitting heat, and almost barren except for some stunted vegetation. Even the soil is atypically brownish red resembling congealed blood (Debi 2011: 55). At the onset of the story, the author does away with the popular romanticism often associated with the Adivasi (tribal) population mainly through their depiction in Hindi films. The newly employed relief officer, Mr Singh, on his first trip to Lohri, had assumed that he would get to see Adivasi men playing flutes and women dancing around with flowers in their hair and running from one hill to another. Now their almost naked, worm-infested, and emaciated bodies disgust him. In his newly assigned post, which he only has to 'suffer' through for three months, the young officer eagerly thinks about returning to Ranchi, whose light and glitter he has left to come to this scorched, disgusting place (Debi 2011: 56f). There is, however, another reason why the land is allegedly abhorrent - because of the inhabitants of the land, the Agariya people who are seemingly averse to their own development. They are known to sell off their land and agricultural resources to moneylenders and are too impatient to wait for crops to mature, arguing that they cannot starve until then. However, there is a legend connected to their past, which is both proud and cursed, and speaks of different Agariyas, distinct from their alleged lazy, obnoxious character that the relief officer comes to know from the block development officer. These people are the descendants of the asura or demons and were fire eaters, men of iron, whose livelihood was to extract iron ore from the earth and make ironware. However, their ancestor and king Logundi, blinded by his power, challenged the Sun god to a fight and eventually lost to him. The Sun god destroyed the king, his eleven brothers, and the burg as well, only Logundi's wife, who was in a different village, survived. Later the wife gave birth to a son named Jalamukhi, who again challenged the Sun in a battle and brought down an irreversible curse on the Agariyas that all their wealth earned by mining ore would turn into ashes and

${ }^{9}$ I have used the original Bangla versions of the stories Sishu and Sandes. Mahdu: A Fairy Tale is translated by the author herself. Unless otherwise stated, all translations used in this article are my own. 
their land would turn barren. In a conflict with the Indian government over iron ore mining, the Agariya people avenged the destruction of their ancestral land by killing the team of geologists who had blasted and blown up the hills and then disappeared into the forest without a trace.

The poignantly satiric treatment of the themes of law and lawlessness is revealed to the readers through the way the government officials encroach upon the lands of the tribal population for minting money through mining ores and the subsequent efforts to hunt down the indigenous people for attempting to defend the land and nature that rightfully belongs to them. Debi here points at a massive failure of decolonisation: that of the unaltered condition of the tribal and indigenous people of India and their systemic oppression at the hands of their own government. Tribal people were under persecution in the colonial regime on the pretext of opposing various 'development projects' which depleted the natural resources and disturbed the holistic connection between the indigenous people and their habitat. Furthermore, they were also criminalised for resisting the aggression of the colonial government ${ }^{10}$. This narrative stays unaltered in the postcolonial society as well. In the Block Development Officer's (BDO) constant reference of the Agariyas as 'obnoxious' and 'stubborn', and responsible for their own sufferings, one still sees a reflection of that colonial criminalisation of the tribes. In addition, the relief officer's feeling of irritation and betrayal that the tribal people do not stand in a queue to receive relief but steal provisions, takes us to the much-discussed terrain of disciplining the bodies in a totalitarian regime (see Claeys 2017: 195). $\mathrm{Mr}$ Singh listens to the curious incidents of relief material being stolen at night by strange 'creatures' resembling little children.

The narrative develops steadily and arrives at a climax when the relief officer, asleep in his tent at night, hears noises outside and driven by a stubborn anger generated by the feeling of betrayal over his noble intention of helping the Agariyas now and rehabilitating them later, chases these creatures to catch the thieves. As a result, he discovers the truth, that these are not children but have long white hair, women, who have dry, hanging breasts. The officer is confounded, and fear engulfs him with the realisation that these are grown up people. An old man from the group comes too close and rubs his dry, shrivelled penis against his body. While the creatures indulge in a show of mocking him with their stunted, dry, arid, desiccated bodies, the officer loses his mind with

${ }^{10}$ See Tolen (1991: 106 - 125), and Schwarz (2010). 


\section{Sukla Chatterjee}

the anguish of realisation of what these people are and why they are like that. Their giggles stun him and render him speechless, only capable of shedding tears.

Debi describes the scene:

He cannot speak. Standing under the moon, while watching them, listening to their giggles, feeling their genitals rub against him, the undernourished body of an average Indian and their laughable height seems like civilisation's heinous crime, one feels like a death convict, and for their midget stature the relief officer condemns himself to [a] death sentence and lifts his gaping open mouth toward the moon. They dance, laugh, rub their dry withered penis[es] on his body; now his only way of redemption is to shatter the horizon with a cry like a mad dog. But why does the head not order the voice to break out in a scream? Tears roll down his eyes (Debi 2011: 65).

The prototypal inhabitants of the realistic third-world dystopia are benumbed people with blocked consciousness cohabiting with the sub-humans, who are occupying a dystopic space within the larger 'normally functioning' society, Debi, in the final lines of her story, jolts the protagonist out of his daze and forces him to realise the heinous ways in which the regime works. The botched up social system that the author portrays, and the government's neglect of its own people are the central ideas behind the microcosmic dystopia that Lohri is, further perpetuated by the moneyed class' self-justification and the justification of the indigenous people's appalling condition. One can see the indigenous bodies as the topos on which injustice, neglect, deprivation and eventually death is being played out as the ultimate expression of sovereignty ${ }^{11}$ of the state. Sishu exemplifies a system where a part of the population is deprived of their livelihood and left to starve, while the government makes insignificant effort to redress their crisis. The starved, stunted and barren bodies of the 'creatures' become the bio-political body on which the totalitarian regime exerts its power. With the individualised action of disciplining the bodies coexists necro-

${ }^{11}$ See Mbembe (2019:66): 'The ultimate expression of sovereignty largely resides in the power and the capacity to dictate who is able to live and who must die. To kill or to let live thus constitutes sovereignty's limits, its principal attributes'. 
politics, which is carried out on the tribal people. Lohri can be the archetypal dystopia whose rightful inhabitants starve and die out while the government officials spread the propaganda of their stealing relief or their alleged unwillingness to work for subsistence. While Western dystopias like The Handmaid's Tale (1985) have employed the trope of using women's bodies as breeding machines, the women of Lohri's dry hanging breasts and barren, malnourished bodies along with their inability to produce children exposes the other end of the spectrum, where starvation wipes out an entire population and adds to the force of necropolitics in its grimmest and darkest facet.

Physical hunger, poverty, and impoverishment have been at the heart of the realist dystopian fiction. In Sishu, the small, impoverished men and women, through their mocking of the relief officer, expose the travesty of the failed promises that a sovereign government made to its citizens.

They also jeer at all other well-fed bodies who look for justification of their starvation or stay apathetic. And finally, the dystopia of emaciated bodies mocks human civilisation. Debi herself writes in the context of Sishu:

Starvation over generations can reduce ordinary sized human beings to pygmies. Of course, the starving Agariyas are savagely angry at a system under which some people eat three meals a day while they are forced to starve! For I believe in anger, in justified violence, and so peel the mask off the face of the India that is projected by the Government, to expose its naked brutality, savagery, and caste and class exploitation; and place this India, a hydra headed monster, before a people's court, the people being the oppressed millions (Debi, as quoted in Syal 2016: 27487).

The sacrifice of its indigenous citizens in a dystopian society perpetuates the nightmare of dystopia. In Sishu, the starving bodies of the Agariyas serve as a human sacrifice to a regressive state and its brutally flawed policies. In addition, central to the plot, is the night of discovery of the 'creatures' by Mr Singh, which itself is like a nightmare, and both these aspects serve as key dystopian devices in Debi's story. Her stories draw our focus to a microcosm of propaganda (blaming the tribal people about their plight), barbarism (of the democratically elected government and state machinery), and inhumanity amidst a generally 'well-functioning' society, like the rotten core of an apparently healthy-looking apple. The end of colonial regimes ushered an era of utopian 


\section{Sukla Chatterjee}

hopefulness in decolonial societies like India. Liberty, self-determination, equality, freedom from exploitation were some of the founding principles of a newly freed country. Global capitalism had shown a particularly grim side of human existence and India, still reeling from the aftermath of the onslaught of colonialism struggled hard to pick up the pieces and start anew.

The imagined blueprint of a consolidated modern Indian nation became a utopia promised to its citizens. While the founding fathers like Mahatma Gandhi, Jawaharlal Nehru, and Rabindranath Tagore offered their visions of the new nation (see Ashcroft 2017: 114 - 132), what emerged most prominently in the national imagination was the figure of the mother: Mother India $^{12}$, who has the power to contain her children, irrespective of their caste and class divisions and to nourish, protect, and provide for them through her self-sacrifice. Comple-menting the figure of the martyr mother was also Gandhi's ideals of non-violence which had gained enormous popularity during India's struggle for freedom. Mahasweta Debi here exposes the utopian ideologies of the founding fathers, whose dreams had remained unfulfilled and promises undelivered to a section of Indian citizens. In fact, the nation itself disguised as a killing machine robs indigenous populations of their means of sustenance. Thus, Debi turns the nation itself into a dystopian entity subverting the utopian visions that was once associated with it, thereby putting the failures of a decolonial state at the centre of a dystopian reality.

Sacrificing the indigenous body forms the key content of another dystopian short story, Mahdu: A Fairy Tale, written in 2000, published in 2003 and translated into English by the author herself. This short story of only twelve pages is a compact narrative about a gathering tribe who faces extinction due to the loss of their natural habitat: a lush teak forest of a few thousand acres, which sustained them physically, emotionally and spiritually ${ }^{13}$. However, with

12 See Ashcroft (2017: 116): 'Bankim Chandra Chatterjee's coining of the Mother India ensured that it would continue to haunt the Indian imagination. Such images offer much more powerful focus than "visions of spiritual unity" and the connection between the nation and Mother India was imprinted on the Indian psyche'. However, the image of the mother was far removed from the actual plight of Indian women.

13 'Saga forests provided them with a home. The bride and the groom were first married to saga trees to make the marriage lasting, strong and productive. Saga was the deity they worshipped' (Debi 2003: 102). 
the felling of the teak trees to construct railways, Korjus, the tribe, lost their desire to live. They offered silent resistance to every form of assistance that the government and non-governmental organisations (NGOs) showed them. The story is an instance of a strong to-and-fro narrative, where the author interjects the story of the Korjus with special emphasis on one particular member of the tribe, with glimpses of factual information about human nutrition, and eventually ends the story with strong irony and surrealism. At the introduction of the story, Debi quotes from Josua de Castro's Geography of Hunger (1952) to set the tone. Mahdu, almost like Sishu, is not about 'total hunger' which leads to starvation. But it explores the,

[m] uch more common and more numerically lethal hidden hunger, which for lack of certain indisposable nutritive elements, condemns whole population groups slowly to die of hunger although they eat everyday (Castro [1952] as quoted in Debi 2003: 97).

The story is about the Korjus, another indigenous population living in the Sagwana (teak) forest who lost their means of livelihood when the forest was felled. Korjus become the subject for 'brilliant' research articles on them about their resistance to 'development' and food:

... in-built resistance against progress is killing them. Their mindset controls the body. So, whenever they eat something they are not used to, they become violently ill (Debi 2003: 100).

Eventually their lifespan was reduced to twenty years and they have stubbornly yet peacefully refused any help or relief. Of particular relevance is how the resistance of the Korjus and their refusal to accept help is described:

DEDICATION [the NGO] sank a few hand pumps, but failed to bring the mothers and children to the nutrition centre. They wouldn't come ... they didn't trust us ...

-- were they violent?

-- oh no! Highly civilized, quiet, soft spoken. No violence. A silent satyagraha! Yes...a satyagraha!

-- A great tragedy (Debi 2003: 101).

Gandhi's much lauded non-violent resistance against the colonial re- 


\section{Sukla Chatterjee}

gime stays relevant to and in use, years after 'independence' amongst a dwindling tribe whose livelihood and home, that is, the few thousand acres of saga forest ${ }^{14}$ that was destroyed by the democratically elected government for the purpose of development. The author informs the readers that cutting and clearing of invaluable forests have been a regular phenomenon since the mid19th century due to the building of the Indian railway. As exemplified by the plight of the Korjus, many tribes who were sustained by such forests were not only rendered homeless but also non-existent. Loss of their habitat resulted in the gradual extinction of these tribes:

This death is a slow process. The process continues through quite a number of generations. Nutrition of the body depended upon the food they were used to. And there was their belief, "nature is the provider of food', so integrated with tribal existence. Their psyche is a protected zone. Impossible to penetrate into ... they are dying in the last five or ten decades ... no written report ... very defeating ... (Debi 2003: 100).

A systematic destruction of the ecological balance and as an extension of the tribal population, nonchalance on the part of the government or gross mismanagement, and lack of experience, insensitivity, and the lack of ethics in dealing with the dying humankind, are some of the prominent characteristics of a postcolonial dystopian society, as Debi contends. The story proceeds rapidly as Mahdu, a dying Korju man is kidnapped for the purpose of research and to solve the mystery of why the community would refuse food and to 'investigate into the great Korju extinction mystery' (Debi 2003: 104). Madhu, the 'specimen', is fed intravenously to examine how the emaciated body that has refused food for years, reacts to feeding and nutrition. The ending of the story is somewhat surreal, drawing on the 'fairy tale' element indicated in the title. Through the experimentation on Mahdu's body, the scientists working on nutrition, try to develop a modified version of the Korjus, similar to the experimentation on Shetland ponies and pygmies.

However, that procedure backfires and Mahdu gains an enormous proportion, devouring the popular landmarks of Mumbai, aeroplanes and trains, roaring, 'I am hungry. Feed me'. He drank from the Arabian Sea to quench his thirst and eventually left to write the authentic Korju story in the

${ }^{14}$ Alternatively referred to as Sagwana in the story. 
sky with the stars that would replace man-made myths about the tribe. The ending of the story is allegorical, hinting that Mahdu's body rejected the intravenous feeding and died, since 'His eye balls [eyeballs] mirrored a tall saga resplendent with leafs [sic] and blossoms', (2003: 108) is indicative of the information that Debi provides the readers in the beginning of the story that 'if you lift the eyelids of a dead Korju you will find the imprint of the old saga forest on his or her eyeballs' (2003: 98). Balancing the bitter reality about centuries-long abuse of environmental resources and indigenous lives, that started with colonialism and continues with equal force and vigour in the postcolonial state, with the use of allegory, magic realism, and irony to end the story, is transgressive, subversive and expresses a distortion that further bolsters the impact of the narrative. Besides the author's claim that Mahdu, the Korju will write his own story: 'No man-made Korju myths. Over. Thus the true Korju story began. Mahdu would write it on the sky. He would pluck the stars, arrange them into alphabets and write' (Debi 2003: 108), on one hand this signifies the powerful discursive resistance of the colonised 'other', violating the imposed and received narrative of neocolonial masters, on the other hand it denotes an impossible task. Dead man tells no tales, neither can a dwindling tribe who has refused to speak and more than anything else, live. A piece of land, that was once a utopia for the indigenous people, sustaining and sheltering them, is turned into a dystopia with no hope of a different future. What further magnifies the anti-utopian and apocalyptic impression is the slow but sure march of the tribal population toward self-inflicted extinction through their 'refusal' to develop. The story of Mahdu charts the journey of transformation of a utopia, the Sagwana forest home for the Korjus, into a dystopia, which is embedded in an overall dystopia of the nation. What was once a majestic jungle of tall, gorgeous trees and vegetation providing food and shelter to the tribal population is turned into barren fields. Korjus started living in a settlement which the author calls 'nishiddha bhumi' or the forbidden land,

[t]he Korjus forgot the outsiders and the outsiders forgot them. The timing was great, as the Pokhran Nuclear Explosion took place. Everything became a non-issue to the media, the nation and the powerbarons (Debi 2003: 104).

Thus, the loss of shelter for a part of the tribal population was conveniently forgotten due to the great din and strides toward 'development' the nation 


\section{Sukla Chatterjee}

made, namely establishing itself as one of the nuclear superpowers.

Two central aspects of colonialism that - of exploration and developmentalism - have also been the key aspects of western utopianism (see Ahmad 2009: 3 - 18). Notable postcolonial writers like Debi have voiced their concern over the kind of modernisation and development that is selective and has a strong capitalistic base. Debi, in particular, repeatedly took up the topic of development that ruins the ecological balance between man and nature to write her dystopian narratives. She further underscores the fact that both in the colonial and neocolonial societies, the presence of the 'irrational' 'primitive' and 'backward' are important to continue with the materialistic development and eventually their elimination.

The hungry body receives a unique and different treatment in Debi's short story Sandes, which opens with the spectacle of a man, eating glass at a party, as a way of entertaining the guests. Chintamani Desai, the host, is a generous and affluent businessman, a sugar dealer, who not only throws opulent parties but also, as a way of diversion and celebration, hires different kinds of people with unusual talents to perform at his parties. On one of those occasions a man devoured a live cobra, in another, a circus girl danced inside a tiger's cage. At Desai's parties, these kinds of entertainment are a must. This time, while the performer eats glass, next to him is spread a buffet table laden with all kinds of food for the guests. On silverware, on display, are fried crispy brown fish, chicken pulao, crab meat in white sauce, blackcurrants, ice cream, fruit cocktails, and several other varieties of exotic fruits. In view of that table is the performer, who had once seen better times, now eating glass to keep himself and his family alive. After his performance, while resting, he eyes the table on which the feast is spread out. There is no end to the procession of food being served and the butler eventually brings some 'Sandes' 15 . The glass eater falls asleep while waiting for his payment. When he awakens, he finds that the party is over, and he is left all alone in the room - with that table still full of food. Driven by his hunger, he takes a cushion cover and starts stuffing it with sweets and cutlets, when suddenly he is discovered by Desai. He finds himself trapped and Desai threatens to call the police or set the dogs on him unless he eats more glass to entertain him. Trapped and desperate to leave without getting arrested, the performer starts eating glass again. The reader is informed that Chintamani Desai is someone who is bored with life. By throwing parties to

${ }^{15}$ Sweets, usually dry and made from milk. 
entertain himself and his friends, he is obsessively and continuously looking for thrills and one way of thrilling himself is to procure performers who perform dangerous feats. Soon after he forces the performer to continue eating glass, the man chokes, collapses and later dies in the hospital. Chintamani Desai dies as well, from too much excitement, which his heart could not bear.

In this story, Chintamani Desai's house serves as a microcosm of both a utopian and a dystopian society. While the rich are fed and entertained, exemplifying a hedonist utopia, poor, desperate people are hired, trapped, and even killed so that the rich can derive some adrenaline rush from the spectacle. In that microcosmic dystopia, a performer can gaze at the food but not touch it and once he breaks the rules, he is trapped; death becomes the only way of escaping that cage. However, one could not have assumed a safe passage for the glass eater had he not touched the food, since Desai deliberately looks for ways to risk the lives of his 'entertainers'. The story is a scathing censure of a society deriving pleasure from unnecessary cruelty and using destitute and compelled hungry bodies as entertainment and spectacle. The portrayal of sharp distinctions in the room, in the form of opulent food, bejewelled women and dancing men, side by side with a performer eating glass for a little money illustrates the economic inequality and division-ridden reality of a society, as well as the numbness of the collective conscience. Dystopias often occupy the no-man's land between satire and tragedy (Gottlieb 2001: 13 - 15). Sandes aptly fits the description, because what started off as a bitter satire, eventually culminates in a tragedy with the loss of the protagonist's life. What constitutes loss in dystopia can manifest on different levels, especially in Western dystopias where the loss of individual and private identity is considered a classic dystopian loss.

In a massively unequal and cruel third world society, loss of one's life for the entertainment of a rich man can simultaneously symbolise the ultimate loss (for the victim and his family) or no loss at all (for the society), for human lives in such a space are cheap and even worthless. A man loses his right to live while catering to the whim of another - this is how a quintessential 'third world' dystopia operates, where the individual falls prey to the collective. As in Sishu, Sandes also embodies the element of an impenitent population through a striking and intense depiction of humanity that has stopped feeling, as exemplified in the following passage:

But what happens if there is a little miscalculation? What if while 


\section{Sukla Chatterjee}

eating the cobra, the performer swallows the yellow poison-filled venom sack? Or if someone forgets to sedate the tiger on the day the girl is supposed to dance in the cage? And what if the tiger gets irritated and pounces on the girl? Will not these ever happen? This is exactly what Chintamani Desai wants to know. With the man eating the glass, he had expected that blood would ooze out of his throat. That is why he bought thick glass. Then he learned that thick glass was actually more convenient for him [the glass eater] (Debi 2011: 99).

Toward the climax of the story, the numbness of the human heart is deftly described in the way Desai almost 'plays' with his prey. Forcing and cajoling him to resume eating glass in spite of the performer's repeated requests to let him go, Desai lures the performer with the offer of more money. Debi writes about Desai's reaction:

Chintamani Desai glances at the man with a thoughtful look. For a while, he is the master of the man. If he wants, he can keep him or get him arrested; but he must admit that catching a thief alone is making him feel good. The doctors tell him to do whatever makes him feel good. Chintamani Desai forgot everything and dropped a few grapes in his mouth. [...] he felt the sugar in his blood and the juice of the grapes are mixing together to form alcohol. If not, why is there so much commotion in his veins or behind his ears? He did not drink alcohol (Debi 2011: 98).

This passage is a fitting example of what Andrew Milner (2009) calls 'apocalyptic hedonism', a,

[j] uxtaposition of light and shade, cheerfulness and death, ... a textual erotics deriving from the simultaneous juxtaposition of the terrors of imminent extinction and the delights of yet a more immediate hedonistic affluence (Milner 2009: 835).

The notable point is that, here the delight and excitement of Desai is caused by the apprehension of the glass eater's death, and that frenzy becomes potent enough to also bring about his own death. While dystopia has been mainly about dictatorial regimes, state violence, and mass oppression, Sandes exposes the 
violent autocrat inherent in human character and that anyone, with enough power over the other, can assume the role of an oppressor.

\section{Conclusion}

In conclusion, I wish to bring forth a couple of points: firstly, vernacular dystopian writings can be seen as non-modular ${ }^{16}$ dystopias, where postcolonial societies need not consume, as dystopian literature, what the West has produced. The genre of dystopian writing can be adapted, modified and rewritten according to the needs and relatability of a particular society. The dissent that postcolonial scholars such as Partha Chatterjee has voiced regarding the West's tendency to provide modular nationalisms to be followed by the postcolonial societies, also applies to the Western canonical genres and how postcolonial societies would understand that their 'anticolonial resistance and postcolonial misery' (1993: 5) are determined by the Western societies, rendering the former as perpetual consumers of modernity (Ibid.). Hence, it is important to highlight the contribution of writers like Debi whose authentic portrayal of a decaying society offers us the kind of insight from which many writers steer away. The three separate stories are political satire culminating in tragedies and which congeal together to form a solid dystopian structure. What is unique about Bangla vernacular dystopias is their politically different stance compared to the futuristic-speculative genre of Western dystopias. While most examples from the latter serve as warnings by showcasing hypothetical societies under totalitarian regimes, vernacular dystopias instrumentalise universal realities like poverty and hunger to expose the pervasiveness of dystopia.

For societies that have dealt with humanitarian crises like famines, destruction of nature and colonial exploitation, dystopia forms a part of everyday reality; it is traumatisingly intimate and personal as well as collective and those societies exemplify how totalitarianism is embedded within democracy, as Achille Mbembe notes,

[t]he brutality of democracies has simply been swept under the carpet. From their origins, modern democracies have always evinced their

${ }^{16}$ I have borrowed the term following Partha Chatterjee's coinage of modular nationalisms in his essay 'Whose Imagined Community?'. See Chatterjee (1993: 3 - 13). 


\section{Sukla Chatterjee}

tolerance for a certain political violence, including illegal forms of it. They have integrated forms of brutality into their culture, forms borne by a range of private institutions acting on top of the state, whether irregular forces, militias, or other paramilitary or corporatist formations (Mbembe 2019: 17).

Secondly, the poetics of dystopian writing in Bangla show us the difference between projecting one's fear of catastrophe in the future and responding to the catastrophe at hand. Hence, while the former is based on imagination, the latter brings into light the facts and figures. Use of emotions as a literary tool is another significant aspect of vernacular dystopias in general and the examples that were discussed in particular, since often writers narrated disasters with emotions to empathise with the victims who are themselves not at fault for their plight. Narrating dire circumstances and disasters with emotions has been a strategy of vernacular writers since the colonial period when they used their pen to depict emergencies and catastrophes: Bhattacharya talks about the emergence of the,

[1]iterary form [in the 19th century] where emotions, ethics, conscience, and melodrama of the catastrophe were inter twined with the features of reasoning, analysis, journalism, ethnography, and satire on the British colonial and the native bourgeois establishment (Bhattacharya 2017: 61).

Finally, Debi's dystopias pose the question: What went wrong that a newly independent society with ideals of equality and justice turns into a dystopian nightmare for a certain section of its citizens? Debi exemplifies that colonialism is a perpetual process and that egalitarian states are still utopian since the division between the centre and the margin will always remain and the regime will continue to feed on its marginalised population. Debi is here writing back at the postcolonial nation state that, following Gottlieb's definition, is a society that

[p]uts its whole population continuously on trial, a society that finds its essence in [...] disenfranchising and enslaving entire classes of its own citizens, a society that, by glorifying and justifying violence by law, preys upon itself. Like a dysfunctional family that maintains its 
framework but is unable to fulfil its function to advance the good of each member of the family, who would, in unison, form a community, dystopian society is what we call today dysfunctional; it reveals the lack of the very qualities that traditionally justify or set the raison d'être for a community. As a result, dystopian society is ultimately a moribund, death-bound society that is incapable of renewal, where the ruling elite cling to their existence as parasites on their own people, whom they devour in the process (Gottlieb 2001: 40f).

While Western dystopias mostly leave the reader with the suspense that if the downward spiralling of society into the 'hypothetical monster state' (2001: 267) can still be prevented, Mahasweta Debi's dystopias show that spiralling down is complete. One can unpack her stories, to find the signature dystopian pessimism and anger accompanying the narratives of brutality. One also finds the resilience of the marginalised in their everyday survival within a dysfunctional society. Her short stories are less for entertainment and more for serious pondering and action. Debi (1999: viii-ix) herself remarks, ... I desire a transformation of the present social system [...] After thirty-one years of independence, I find my people still groaning under hunger, landlessness, indebtedness and bonded labour. An anger, luminous, burning, and passionate, directed against a system that has failed to liberate my people from these horrible constraints, is the only source of inspiration for all my writing ${ }^{17}$.

In Debi's stories, subalternity is closely linked to dystopianism and this introduces her uniqueness as a writer of dystopian literature. She does not unwrite and rewrite the Western literary canon but introduces a completely novel and current flavour to the genre, through her focus on the subaltern. Her writings contribute to the heterogeneity of the canon by posing an ideal for transformation whereby multicultural literature about the subaltern can add to its expanse. Furthermore, reading Mahasweta Debi's dystopian short stories in the global context of a dystopian narrative adds to the humanistic reading of such texts, which to me is one of the most crucial contributions that vernacular dystopias can bring to the global literary table. Even in the most pessimist of times, vernacular dystopias rarely fail to arouse pathos, even though canonical Western dystopias like Orwell's 1984 send the message that human values and tender emotions are out of place in a totalitarian, materialist, industrialised/

${ }^{17}$ See Debi 'Introduction,' (1999: viii - ix). 
technological world, Debi's stories do it with a more empathetic and humane touch. While vernacular dystopias with their all too recognisable topos, deprive the readers of the reassurance of a future that might go wrong, the assertion that dystopia can very much be a part of the everyday reality of the Third World might indeed trigger the possibility of a revolutionary transformation.

\section{References}

Ahmad, D. 2009. Landscapes of Hope: Anti-Colonial Utopianism in America. London \& New York: Oxford University Press.

Ashcroft, B. 2017. Utopianism in Postcolonial Literatures. London \& New York: Routledge.

Ashcroft, B. 2017. Writing and Re-Writing India. In Utopianism in Postcolonial Literatures. London \& New York: Routledge.

Atwood, M. 2009. The Year of the Flood: A Novel. New York \& London: Nan A. Talese/ Doubleday.

Baccolini, R. \& T. Moylan (eds.). 2003. Introduction: Dystopias and Histories.

In Baccolini, R. \& T. Moylan (eds.): Dark Horizons: Science Fiction and the Dystopian Imagination. London \& New York: Routledge.

Bagchi, B. (ed.). 2012. The Politics of the (Im)Possible: Utopia and Dystopia Reconsidered. New Delhi: Sage Publications.

Bhattacharya, S. 2017. The Question of Literary Form: Realism in the Poetry and Theatre of the 1943 Bengal Famine. In Ulanowicz, A. \& M. Basu (eds.): The Aesthetics and Politics of Global Hunger. Cham, Switzerland: Palgrave Macmillan.

Castro, J. 1952. The Geography of Hunger. New York: Little, Brown and Company.

Debi, M. 1998. Bitter Soil. Chanda, I. (trans.). Kolkotta: Seagull Books.

Chatterjee, P. 1993. The Nation and its Fragments: Colonial and Postcolonial Histories. Princeton: Princeton University Press.

Chatterjee, S. 2019. Tarashankar Bandopadhyay's Caitālì ghürni and The Dystopia of Hunger. Open Library of Humanities 5, 1.

http://doi.org/10.16995/olh.35

Claeys, G. 2017. Dystopia: A Natural History. A Study of Modern Despotism, Its Antecedents, and Its Literary Diffractions. London \& New York: OUP. Debi, M. 2011. 75 ți galpa. Karuṇa Prakasani. 
Debi, M. 2003. Mahdu: A Fairy Tale. In Singh, P.K. (ed.): The Politics of Literary Theory and Representation: Writings on Activism and Aesthetics. New Delhi: Munshiram Manoharlal Ltd.

Debi, M. 1999. Introduction. Five Plays. Kolkotta: Seagull Books.

Eckart, V. \& A. Boller (eds.). 2015. Dystopia, Science Fiction, PostApocalypse: Classics, New Tendencies, Model Interpretations. Trier: Wissenschaftlicher Verlag.

Gottlieb, E. 2001. Dystopian Fiction East and West: Universe of Terror and Trial. Montreal: McGill-Queen's University Press.

Ilott, S. 2015. New Postcolonial British Genres: Shifting the Boundaries. Cham, Switzerland: Springer.

Landry, D. \& G. MacLean (eds.). 1996. The Spivak Reader: Selected Works of Gayatri Chakraborty Spivak. London \& New York: Routledge.

Levine, C. 2015. Forms: Whole, Rhythm, Hierarchy, Network. Princeton: Princeton University Press.

Mayes, P. 2003. Language, Social Structure, and Culture: A Genre Analysis of Cooking Classes in Japan and America. Amsterdam: John Benjamins Publishing Company.

Mbembe, A. 2019. Necropolitics. Durham, NC: Duke University Press.

Meyers, J. (ed.). 1975. George Orwell: The Critical Heritage. London \& New York: Routledge \& Kegan Paul.

Milner, A. 2009. Changing the Climate: The Politics of Dystopia. Continuum 23, 6: $827-838$.

Premchand, M. 2011. The Nature and Purpose of Literature. Social Scientist 39, 11/12: 82.

Schwarz, H. 2010. Constructing the Criminal Tribe in Colonial India: Acting Like a Thief. New York: John Wiley \& Sons.

Sen, S. 2012. A Parliament of Women: Dystopia in Nineteenth-century Bengal Imagination. In Bagchi, B. (ed.): The Politics of the (Im)Possible: Utopia and Dystopia Reconsidered. New Delhi: Sage Publications India.

Singh, P.K. (ed.). 2003. The Politics of Literary Theory and Representation: Writings on Activism and Aesthetics. New Delhi: Munshiram Manoharlal Ltd.

Syal, J. 2016. Tale of the Dispossessed - Mahasweta Debi's Little Ones. International Journal of Current Research 8, 3: 27487.

Tolen, R. 1991. Colonizing and Transforming the Criminal Tribesman: The Salvation Army in British India. American Ethnologist 18, 1: 106 - 125. 
Sukla Chatterjee Faculty Member and Postdoctoral Fellow University of Bremen

Germany sukla.chatterjee@uni-bemen.de 